\title{
Note on Editorial Method
}

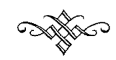

All citations of Pasternak's and Tsvetaeva's writings appear in the text and refer to the following multivolume collections:

Boris Pasternak, Sobranie sochinenii v piati tomakh, ed. A. A. Voznesenskii, D. S. Likhachev, D. F. Mamleev, A. A. Mikhailov, E. B. Pasternak (Moscow: Khudozhestvennaia literatura, I989-92).

Marina Tsvetaeva, Sobranie sochinenii v semi tomakh, ed. Anna Saakiants and Lev Mnukhin (Moscow: Ellis Lak, r994-95).

The two other publications cited in the text are:

DL Rainer Maria Rilke, Dykhanie liriki: Perepiska s Marinoi Tsvetaevoi $i$ Borisom Pasternakom, ed. K. M. Azadovsky, E. V. Pasternak, E. B. Pasternak (Moscow: Art-Fleks, 2000).

DNV Marina Tsvetaeva and Boris Pasternak. Dushi nachinaiut videt': Pis'ma I922-I936 goda, ed. E. B. Korkina and I. D. Shevelenko (Moscow: Vagrius, 2004).

All translations are my own unless otherwise indicated in the endnotes. I have used the Library of Congress system for transliteration, modifying it for surnames to make them recognizable to readers unacquainted with Russian. 



\section{The Same Solitude}


